Journal of Engineering and Applied Sciences 14 (6): 1949-1960, 2019

ISSN: 1816-949X

(C) Medwell Journals, 2019

\title{
Improving Talent Retention in Textile and Garment Industries in Dong Nai Province
}

\author{
${ }^{1}$ Thang Quyet Nguyen, ${ }^{2}$ Thanh-Lam Nguyen and ${ }^{3}$ Nguyen Thanh Long \\ ${ }^{1}$ Faculty of Tourism and Hospitality Management, \\ Ho Chi Minh City University of Technology (HUTECH), \\ Ho Chi Minh City, Vietnam \\ ${ }^{2}$ Office of International Affairs, Lac Hong University, Dong Nai, Vietnam \\ ${ }^{3}$ Faculty of Business Administration, Industrial University of Ho Chi Minh City, \\ Ho Chi Minh City, Vietnam
}

\begin{abstract}
Over the past few years, more and more organizations have well recognized the importance of retaining talent for their sustainable development. How to successfully retain their talents and what are the determinants of the talent retention are therefore, critical. Hence, this study aims at investigating the determinants in textile and garment industries in Dong Nai Province. From the official survey of 214 people who are regarded as talents in related companies, 9 determinants were found, including: personal loyalty, training and promotion opportunities, relationship with colleagues, salary and benefits, nature of work, recognition by organization, working environment, relationships with superiors and type of ownership. Moreover, it is also found that Foreign companies are better in retaining their talents than private ones. Thus, the latter should put more effort to avoid losing their talents to the former.
\end{abstract}

$\underline{\text { Key words: Dong Nai textiles and garment, determinant, talent retention, promotion, retaining, survey }}$

\section{INTRODUCTION}

In the modern economy, the demand for high quality human resources, skilled labour force, etc. is growing while the availability is limited, consequently how to attract talents is more and more important (Menefee and Murphy, 2004). The high rate of turnover is certainly costly and detrimental to the business because it negatively affects the staff's morale, talent, loyalty and ultimately the organizational performance. Therefore, many organizations offer attractive incentives to attract talents and the phenomenon of "leap frog" is becoming more and more popular (Lathitha, 2012). Thus, Botha et al. (2011) argues that the fundamental problem that needs resolved first is how to retain talents for the survival and development of the organization. This is also the permanent question for the leaders to carefully consider in the development of related policies. Mohammed (2016) argues that organizations need to have special policies to retain their talents to create their own competitive advantage through high quality human resources which have been recently referred to as "human capital" because it reflects the true value of human resources in terms of knowledge, skills and working (Armstrong, 2010). Bartel (2004), Becker and Huselid (2006), Rola and Garavan
(2013) argue that human resources are valuable, rare, imbalanced and irreplaceable because they create competitive advantage for the survival and growth of organizations

And, the global economic integration results in fierce competition on markets. In such competition, organizations will have their advantages if they can provide quality products and services at a reasonable cost. This also means that organizations must improve their productivity and labor efficiency. So, investment in machinery, equipment and human resources is considered important. Among them, investment in human resources is more preferred because if human resources fail to be sufficiently qualified to effectively operate modern machinery, facilities, tools, etc., abundant financial resources are also meaningless. Wallis et al. (2004) shows that modern talent is highly skilled, qualified and experienced. Therefore, organizations are actively seeking to utilize the skills, knowledge, experience and capabilities of these talents to create value for their organization. Practically, successfully recruiting a talent is quite difficult but retaining a talent is much more difficult (Tarique and Schuler, 2010; Schuler et al., 2011; Scullion and Collings, 2011). Currently, organizations tend to reduce the turnoverrate of their employees andtry their best to retain

Corresponding Author: Thanh-Lam Nguyen, Office of International Affairs, Lac Hong University, Dong Nai, Vietnam 
their talents togenerally stabilize their business operation and create a good foundation for their sustainable development (Ngethe et al., 2012). According to Ntonga (2007), good management of talent will help organizations to operate better than others. Similar to human resource management in general, talent management also includes key tasks such as attracting, retaining and developing talents (Beheshtifar, 2011). Mohammed (2016) points out that talent management helps organizations have right people with right skills at right time to engage in strategically important decisions that ensure success and improvement of their organizational capacity.

Practically, the business environment is always in a dynamic and changing state which profoundly affects the results and performance of organizations as well as human resources. Therefore, human resources, including talents, must be properly managed to make the most of the available resources for the organization benefits (Singh and Dixit, 2011). To do that, identifying factors affecting the psychology and behavior of workers is important. Hence, several researchers have paid special interest in the field, for example, Ellickson and Logsdon (2002), Ali and Ahmed (2009), Khan et al. (2010a, b), Rice et al. (2012), Tausif (2012) and Thunnissen et al. (2013) explore the factors that affect job satisfaction and job satisfaction; Ramlall (2004), Coughlan (2005), Wang and Hsu (2006), Trang (2010) and Allada and Nittala (2012) concern about the factors that influence the attachment and loyalty of employees to organizations meanwhile, Dung (2005) points out the relationship between job satisfaction and other factors such as job characteristics, promotion opportunities, leadership, co-workers, wages, benefits and working conditions. Chew (2004) proposed a model that determines the relationship between loyalty and the 9 factors, including: the alignment between individual and organization, reward and recognition, occupational training and development, challenging opportunities, leadership behavior, workplace relationships, corporate culture and structure, working environment and internal communication.

In recent years, many reports from professional organizations show that many provinces and cities in Vietnam are lacking of qualified human resources for textile and garment enterprises; consequently, there is an intense competition to attract and retain talents among the enterprises in the business sector. Therefore, the rate of labor turnover (or "leap frog") in this sector is very high (CAF., 2011).

In Dong Nai, the phenomenon of leap frogging in this sector happens not only in ordinary workers but also in management personals. Therefore, retaining talents is always one of the top concernsamong textile and garment enterprises in Dong Nai Province. In order to help these businesses effectively improve talent retention, this research aims at identifying factors affecting talent retention and propose managerial implications to improve the talent retention.

\section{MATERIALS AND METHODS}

Definition of "Talent": Gagne (2000) claims that talents are more capable and superior than others working in the same field. Williams (2000) describes talents as those who often demonstrate exceptional ability and achievement or through a range of activities and situations in a specialized and narrow field of specialization and lead in the field and prove to be highly effective in almost every situation. Similarly, Axelrod et al. (2001) define talents as capable of carrying out their assigned tasks efficiently and achieving high results in a particular environment or Michaels et al. (2001) define talents as those with "outstanding ability" in terms of inner capabilities, skills, knowledge, experience, intelligence, judgment and proper attitudes to effectively deal with assigned tasks. Or according to Stahl et al. (2007), talents are ranked high in capacity and performance.

At the same time, Thorne and Pellent (2007) argue that a talent is someone with a strength that is superior to others and that he or she is capable of performing better than others without having to work hard. Thus, talents have high professional qualifications, professional ethics as well as good dignity and they are usually respected. They usually have intelligent and scientific working methods, propose good solutions for their leaders, offer innovative ideas to create a turning point or timely solve problems happened in the business activities. As such, this study uses the concept proposed by Thorne and Pellent (2007) to refer to "talent".

Talent management: Talent management can help systematize the activities and processes that focus on the organization's critical positions to optimize the organizational performance. However, according to Ready and Conger (2007), Cappelli (2008), Collings and Mellahi (2009), Makela et al. (2010), one of the great challenges for talent management is the shortage of available talents for organizations. The importance of talent management for organizational success has been confirmed by many scholars (Beechler and Woodward, 2009, Gallardo-Gallardo et al., 2013; Hartmann et al., 2010; Iles et al., 2010). 
Being able to identify key positions for talents is the first and most important step in any talent management strategy (Michaels et al., 2001; Axelrod et al., 2002; Frank et al., 2004; Boudreau and Ramstad, 2005). According to Gallardo-Gallardo et al. (2013), human resource managers need to recognize that human resources are a valuable asset for organizations to create their sustainable competitive advantages and other resources should be considered in direct relation to the talents who make up the organization's human resource strength. According to Lewis and Heckman (2006) in order to effectively manage talent, organizations need to: change the mindset from human resource management to talent management; enhance the development of talents through: employee projects, identifying needs and managing employee processes by internal rotation of key positions and focus on talent management.

According to Collings and Mellahi (2009) and Vaiman et al. (2012), business organizations consider talent management as a strategic tool to improve their competitive strength. Attracting, developing and retaining best employees in terms of ability and virtue play an important role in the future success of their organizations (O'Leary et al., 2002; Scullion and Collings, 2010).

Talent retention: According to Hassan et al. (2011) retaining a talent is to keep a person who has had contributions or has a potential to contribute significantly to the organization's performance and development. Till now, there is no definite definition of talent retention, however, it can be understood that retaining a talent is all about how to keep talents stay and serve the organization with their utmost desires. Although, it is fairly simple to understand like that, organizations are still facing huge challenges in retaining their talents as well as attracting other talents and skilled workers. According to Singh and Dixit (2011) due to scarcity of talents in the market in order to attract talents, organizations must have attractive policies which are also quite costly. In addition, if a talent is dissatisfied with the organization or the current job, he/sheis more likely to switch to another organization because they are always valuable on the labor market. Therefore, retaining a talent in the organization is far more important than attracting new one.

Factors that affect the retention of talent: Dunford et al. (2010) argue that rewards based on stock ownership are often used to align organizational goals, personal goals and motivational goals; hence, it can be used to attract and retain talents. However, Matkeri (2011) thinks that, it is easy to attract and retain talents in the form of wage incentives and performance bonuses. Talent wants long- term association with the organization and wants to contribute to the organization but if they are dissatisfied with issues such as wages and income, the balance between life and work, career development and personal skills, they tend to easily switch their jobs.

Tansley (2011) believes that a good and fair environment is needed to retain talent. It is also important for organizations to: provide essential working conditions for good employees to effectively perform their tasks andhave promotion opportunity in their careers; offer adequate benefits and welfares to encourage them to perform better; eliminate negative factors such as those who work stagnantly, ineffectively or envy others, etc.; create proper conditions for talents to feel that they are important in the organization because they are an indispensablecomponent in the organization; this can be done by recognizing their contributions and good performance. According to Logan (2000), talent retention is driven by a number of important factors: organizational culture, communication, strategy, salary and benefits, flexible scheduling and opportunity to develop their talents. Meanwhile, Masibigiri and Nienaber (2011) argue that talent retention is a multifaceted concept influenced by various factors, including the commitment of talent, engagement, communication environment, leadership styles and intrapersonal interactions and human resource management policies.

Maurer (2001) argues that in order to retain talents for organizational growth, organizations need to make them satisfied with their job. Luddy has identified 5 factors that influence job satisfaction, including: the nature of work, opportunities for training and promotion, leadership, colleagues and income. In Vietnam, Dung (2005) discovered four factors that made employees satisfied with their jobs: wages, colleagues, leaders and promotion opportunities. And this is also the factors that affect the talent retention.

On the other hand, talent tends to be more engaged if they are involved in decision making in the organization because it gives them a sense of respect and importance in the organization. They feel empowered when they have the right to contribute their minds in decisions for the development of their organization (Wagner, 1994; Pearson and Duffy, 1999; Moorhead and Griffin, 2004). Moreover, Cronin and Becherer (1999), Jun et al. (2006) found a strong correlation between reward, recognition and work engagement. If the organization has a system of reward and recognition of contributions in a transparent, public and fair manner, the performance of the organization will be significantly increased.

In addition, there are other affecting factors to be named as: performance evaluation, job security, good 


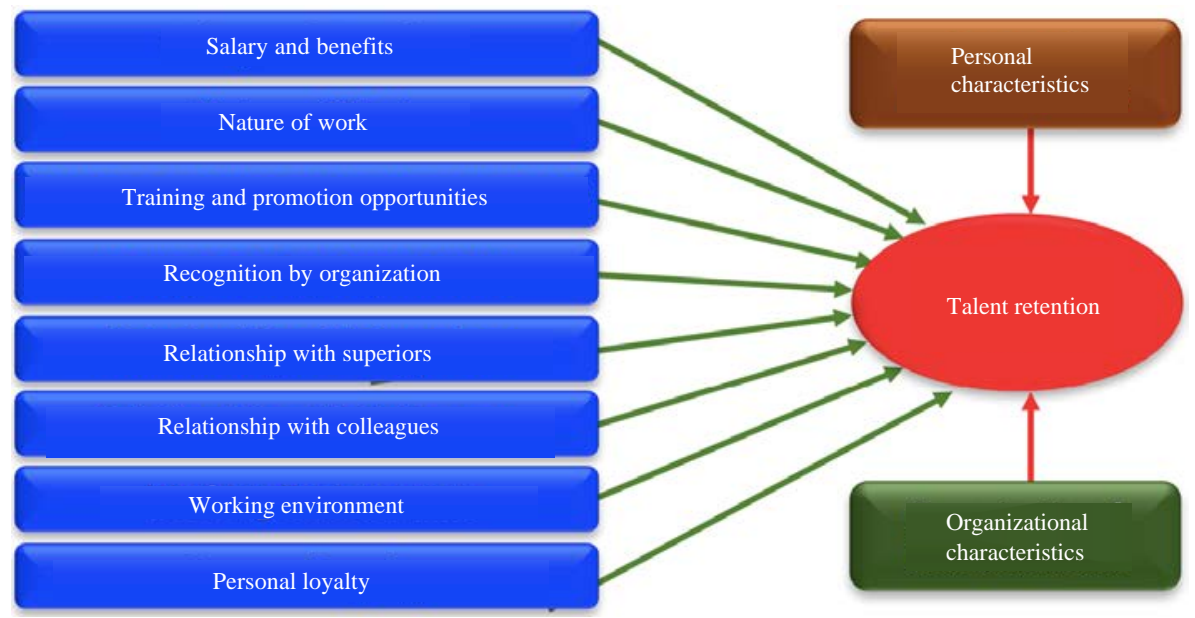

Fig. 1: Proposed research model

working conditions and environment, ability to participate in activities in the organization, disciplinary policy and the organization's care in helping with personal problems (Linder, 1998). Especially, the interesting nature of work (Harpaz, 1990; Linder, 1998; Hossain and Hossain, 2012), work motivation (Chowdhury, 2017; Abadi et al., 2011) are also important drivers because they create mental strength that helps employees complete their tasks and accomplish their organizational goals. Safiullah (2015) identifies the following factors: employment security, relationships with superiors, rational assessment based on performance, trustworthiness, cooperative spirit among colleagues, good working environment, adequate opportunities for personal development, involvement in important issues and appropriate assignments.

According to Yen et al. (2015), talent retention is also affected by the loyalty of individuals which is a difficult element to be measured accurately. For talents, their loyalty often arises from their true feelings towards the organization and this will help them refuse opportunities in other organizations even though they will have better opportunities like better salary, better working conditions or they can be loyal to the organization due to the ethical standards they pursue. Guillon and Cezanne (2014) pointed that loyal employees are often satisfied with their work and do their jobs with high productivity. Employee loyalty is often linked to the way organizations treat their employees. If employees feel they are treated fairly and have the best opportunities in their organization, they will rarely switch their jobs (Khuong and Tien, 2013; Guillon and Cezanne, 2014; Ibrahim and Al Falasi, 2014; Iqbal et al.; 2015; Martensen and Gronholdt, 2006). And the allegiance mentioned in this study is considered in two respects: the nature of human characteristics and attachment to the organization.
Research method: From the above studies, in addition to the personal and organizational characteristics, there are 8 determinants used in this study as follows: salary and benefits, nature of work, training and promotion opportunities, recognition by the organization, relationship with superiors, relationship with colleagues, working environment and personal loyalty. Therefore, our research model is proposed as in Fig. 1.

Data collection methods: The researcher uses the questionnaire and proceeds through two main steps: pilot research and formal study. Specifically, the pilot research was conducted with the 5 participants who were group leaders from a textile company located in Agtex long binh industrial park to examine the clarity and uniqueness of the survey questions as well as search fortheir comments to refine our questionnaire before conducting our official survey. The content of the observed variables is shown in Table 1 and 2.

Data analysis methods: The author uses a number of methods of data analysis which are widely used in socio-economic studies such as: scale reliability analysis, Exploratory Factor Analysis (EFA) and linear regression analysis. In statistics, the reliability of a scale is evaluated by: Cronbach's alpha coefficient $(\alpha)$ and item-total correlation coefficient for each factor constituting the scale. In the socio-economic field, many researchers agree that when Cronbach's alpha is 0.8 or nearly 1.0 , the scale is considered good, i.e., the consistency of the items in the scale is high; from 0.7 to nearly 0.8 , the scale is rated as good and 0.6 or more is acceptable. In addition, the item-total correlation of a variable must be $>0.3$ to be considered satisfactory. 
Table 1: Investigated hypothesis

Hypothesis

$\mathrm{H}_{1}$; Salary and benefits have positive impacts on talent retention

$\mathrm{H}_{2}$; Nature of work has positive impacts on talent retention

$\mathrm{H}_{3}$; Training and promotion opportunities have positive impacts on talent retention

$\mathrm{H}_{4}$; Recognition by organization has positive impacts on talent retention

$\mathrm{H}_{5}$; Relationships with superiors have positive impacts on talent retention

$\mathrm{H}_{6}$; Relationships with colleagues have positive impacts on talent retention

$\mathrm{H}_{7}$; Working environment has positive impacts on talent retention

$\underline{\mathrm{H}_{8} ; \text { Personal loyalty has positive impacts on talent retention }}$

Table 2: Coding of observed variables

Salary and benefits (LC)

You are paid based on your performance

Your current salary is enough for your family expenditures

The salary is scientifically calculated

You will have higher salary for better performance

There is a favourable treatment policy for talents

There is an appealing reward policy

Relevant insurances for employees are fully implemented

Nature of work (BC)

You are clear with all job requirements and responsibilities

Your work matches your capacity and interest

Your work needs your proactiveness and creativity

Your work brings happiness to you

Training and promotion opportunities (DT)

You are encouraged to have higher education and training $\quad$ DT1

There is an explicit policy for promoting talents $\quad$ DT2

Policies in training and promotion are publicly circulated within the organization

Capable employees are always considered for promotion

DT4

Recognition by organization (CN)

Your good performance is always appreciated

CN1

Employees are complimented and encouraged

$\mathrm{CN} 2$

Your opinions and reflections are welcomed

Employee's opinions are satisfactorily considered

Productivity is one of the key criteria for promotion

$\mathrm{CN} 3$

Relationship with superiors (CT)

Your superiors provide good conditions to favour your work

CN4

Your superiors are friendly and condescending

CN5

Your superiors treat you fairly and unbiased

CT1

Your superiors always try to listen and understand you

CT2

Relationship with colleagues (DN)

Your colleagues are always willing to help each other

Your colleagues love you

There is no conflict between you and your colleagues

Your colleagues always encourage each other

You feel connected with your colleagues

Working envir onment (MT)

You are equipped with necessary tools and facilities

Tools and equipment are in good conditions

Lights and air-conditioners well fit for y our work

Working spaces are kept clean

You feel safe in y our work-places

You feel comfortable in your work-places

Personal loyalty (TT)

Loyalty is your inherent characteristic

You always appreciate loyalty

You want to be loyal with this company

After reliability analysis, satisfied scales will be further analysed with Exploratory Factor Analysis (EFA). In the EFA analysis, three parameters to be carefully investigated include: the number of factors extracted, factor loading and total variance extracted. If the EFA analysis results show that these three conditions are satisfactory, it is concluded that the EFA Model is appropriate, i.e., using the EFA analysis approach in the study is appropriate.
A multivariate regression analysis is also used to analyze the relationship between a dependent variable and multiple independent variablesto predict the degree of dependent variable (with limited accuracy) when the values of the independent variablesare known. In addition, independent-samples t-test and one-way ANOVA are also used to examine the effects of investigated individual or organizational characteristics on the dependent variable in the regression model. 


\section{RESULTS AND DISCUSSION}

Official survey was conducted from February-March 2018 for leaders: department heads/deputy heads and team/production line managers. In addition, there are some participants who were introduced as talents by their leaders in textile and garment enterprises in Dong Nai. A total of 235 hard copies and 459 emails with online links were sent out. There were 186 hard copies (79.81\%) and 97 online observations $(21.13 \%)$ collected. After a screening process, 214 valid observations were used in this study.

Descriptive statistics of surveyed objects: Among the 214 valid observations, Table 2 briefly shows that the survey sample was eligible to represent the overall population.

Exploratory factor analysis: The investigated scales were first analyzed for their reliability by Cronbach's alpha coefficient. Table 3 shows that the Cronbach's alpha values of all eight components are greater than 0.6 , thus, they are reliable for further analysis. In addition, the results of the EFA analysis in Table 4 showed that all eight factors were extracted at an eigenvalue of 1.773 and the cumulative rotation sums of squared loadingsof $70.09 \%$. These indicate that the EFA approach is appropriate in this study. Moreover, the KMO of 0.771 and the Bartlett's test sig. $=0.000$ presented in Table 5 further confirm the appropriateness of the EFA method used in this study.

Results of linear regression analysis: With the 214 valid observations, the average value of "talent retention" (KNDT) in the textiles and garment enterprises in Dong Nai Province was 3.318 on a scale of 5. Thus, talent retention in textile and garment industry in Dong Nai is a noteworthy problem to be carefully considered for proper actions. What factors have affected such retention and what is the importance of each factor. To solve these questions, multivariate linear regression analysis is used in this study. It is expressed as:

$$
\mathrm{KNDT}=\mathrm{f}\left(\begin{array}{l}
\mathrm{LC}, \mathrm{BC}, \mathrm{DT}, \mathrm{CN}, \mathrm{CT}, \mathrm{DN}, \mathrm{MT}, \mathrm{TT}, \mathrm{POS}, \\
\mathrm{GEND}, \mathrm{AGE}, \mathrm{ACA}, \mathrm{EXPE}, \mathrm{OWN}, \mathrm{SIZE}
\end{array}\right)
$$

Where:

$$
\begin{array}{ll}
\text { KNDT } & \text { Ability to retain talents } \\
\text { LC } & =\text { Salary and benefits } \\
\text { BC } & =\text { Nature of work } \\
\text { DT } & =\text { Training and promotion opportunities } \\
\mathrm{CN} & =\text { Recognition by organization } \\
\mathrm{CT} & =\text { Relationship with superiors } \\
\mathrm{DN} & =\text { Relationship with colleagues } \\
\mathrm{MT} & =\text { Working environment }
\end{array}
$$

\begin{tabular}{|c|c|c|}
\hline Aspects & Frequencies & Percentage \\
\hline \multicolumn{3}{|l|}{ Gender } \\
\hline Male & 79 & 36.91 \\
\hline Female & 135 & 63.09 \\
\hline \multicolumn{3}{|l|}{ Age range } \\
\hline$<30$ & 19 & 8.87 \\
\hline $30-40$ & 61 & 28.50 \\
\hline $40-50$ & 93 & 43.47 \\
\hline$\geq 50$ & 41 & 19.16 \\
\hline \multicolumn{3}{|l|}{ Education } \\
\hline$\leq$ High school & 13 & 6.07 \\
\hline Intermediate & 23 & 10.74 \\
\hline College & 35 & 16.36 \\
\hline University & 87 & 40.65 \\
\hline Master & 42 & 19.63 \\
\hline Doctor & 14 & 6.55 \\
\hline \multicolumn{3}{|c|}{ Working experience (Years) } \\
\hline$<5$ y ears & 29 & 13.55 \\
\hline $5-10$ years & 75 & 35.05 \\
\hline$\geq 10$ years & 110 & 51.40 \\
\hline \multicolumn{3}{|l|}{ Ownership } \\
\hline Private & 105 & 49.07 \\
\hline FDI & 109 & 50.93 \\
\hline \multicolumn{3}{|l|}{ Firm size } \\
\hline$\leq 300$ & 17 & 7.94 \\
\hline $301-500$ & 44 & 20.56 \\
\hline $501-1000$ & 50 & 23.36 \\
\hline$\geq 1001$ & 103 & 48.14 \\
\hline
\end{tabular}

$\begin{aligned} \text { TT } & =\text { Personal loyalty } \\ \text { POS } & =\text { Position } \\ \text { GEND } & =\text { Gender } \\ \text { AGE } & =\text { Age } \\ \text { ACA } & =\text { Academic level } \\ \text { EXPE } & =\text { Working Experience (years) } \\ \text { OWN } & =\text { Type of Ownership } \\ \text { SIZE } & =\text { Firm Size }\end{aligned}$

In the first regression run, personal characteristics such as POS, GEND, AGE, ACA, EXPE werefound statistically insignificant in the regression model whereas among the organizational characteristics, only the type of ownership OWN is statistically significant. Table 6 shows the final results obtained from the regression model after removing the insignificant variables.

Table 6 shows that the independent variables are statistically significant, meaning that they have significant impacts on the talent retention of textile and garment enterprises in Dong Nai. Table 7 and 8 shows the importance of each factor affecting the talent retention ranked in descending order on the scale of 5 .

Thus, among the examined factors, only "personal loyalty" was rated more than 4 in the 5 -point scale (4.301/5.00), indicating that every person surveyed has the concept of loyalty as an inherent virtue and always fosters loyalty and want to be loyal to its present organization. Meanwhile, there are other three factors that are below average ( 3 points) and these three factors are 
Table 4: Exploratory factor analysis and scale reliability analysis

\begin{tabular}{|c|c|c|c|c|c|c|c|c|c|}
\hline \multirow[b]{2}{*}{ Factors } & \multicolumn{8}{|c|}{ Components } & \multirow[b]{2}{*}{ Cronbach $(\alpha)$} \\
\hline & 1 & 2 & 3 & 4 & 5 & 6 & 7 & 8 & \\
\hline \multicolumn{10}{|c|}{ Salary and benefits } \\
\hline LC7 & 0.89 & & & & & & & & 0.935 \\
\hline LC6 & 0.89 & & & & & & & & \\
\hline LC4 & 0.87 & & & & & & & & \\
\hline LC3 & 0.85 & & & & & & & & \\
\hline LC2 & 0.85 & & & & & & & & \\
\hline LC5 & 0.79 & & & & & & & & \\
\hline LC1 & 0.75 & & & & & & & & \\
\hline \multicolumn{10}{|c|}{ Working envir onment } \\
\hline MT1 & & 0.88 & & & & & & & 0.900 \\
\hline MT6 & & 0.86 & & & & & & & \\
\hline MT3 & & 0.84 & & & & & & & \\
\hline MT4 & & 0.79 & & & & & & & \\
\hline MT2 & & 0.79 & & & & & & & \\
\hline MT5 & & 0.69 & & & & & & & \\
\hline \multicolumn{10}{|c|}{ Relationship with colleagues } \\
\hline DN1 & & & 0.89 & & & & & & 0.905 \\
\hline DN5 & & & 0.89 & & & & & & \\
\hline DN3 & & & 0.86 & & & & & & \\
\hline DN2 & & & 0.79 & & & & & & \\
\hline DN4 & & & 0.78 & & & & & & \\
\hline \multicolumn{10}{|c|}{ Recognition by organization } \\
\hline CN1 & & & & 0.89 & & & & & 0.887 \\
\hline CN5 & & & & 0.87 & & & & & \\
\hline $\mathrm{CN} 2$ & & & & 0.83 & & & & & \\
\hline CN3 & & & & 0.78 & & & & & \\
\hline CN4 & & & & 0.74 & & & & & \\
\hline \multicolumn{10}{|c|}{ Relationship with superiors } \\
\hline CT4 & & & & & 0.90 & & & & 0.852 \\
\hline CT1 & & & & & 0.88 & & & & \\
\hline CT3 & & & & & 0.81 & & & & \\
\hline CT2 & & & & & 0.69 & & & & \\
\hline \multicolumn{10}{|c|}{ Training and promotion opportunities } \\
\hline DT4 & & & & & & 0.85 & & & 0.826 \\
\hline DT3 & & & & & & 0.84 & & & \\
\hline DT2 & & & & & & 0.78 & & & \\
\hline DT1 & & & & & & 0.73 & & & \\
\hline \multicolumn{10}{|c|}{ Nature of work } \\
\hline $\mathrm{BC} 1$ & & & & & & & 0.85 & & 0.819 \\
\hline $\mathrm{BC} 4$ & & & & & & & 0.83 & & \\
\hline $\mathrm{BC} 2$ & & & & & & & 0.80 & & \\
\hline $\mathrm{BC} 3$ & & & & & & & 0.71 & & \\
\hline \multicolumn{10}{|c|}{ Personal loyalty } \\
\hline TT1 & & & & & & & & 0.86 & 0.740 \\
\hline TT2 & & & & & & & & 0.83 & \\
\hline TT3 & & & & & & & & 0.74 & \\
\hline
\end{tabular}

Table 5: Total variance explained

\begin{tabular}{|c|c|c|c|c|c|c|c|c|c|}
\hline \multirow[b]{2}{*}{ Com. ${ }^{(1)}$} & \multicolumn{3}{|c|}{ Initial eigenvalues } & \multicolumn{3}{|c|}{ Extraction sums of squared loadings } & \multicolumn{3}{|c|}{ Rotation sums of squared loadings } \\
\hline & Total & $\operatorname{Var}^{(2)}(\%)$ & $\mathrm{Cum}^{(3)}(\%)$ & Total & $\operatorname{Var}^{(2)}(\%)$ & $\mathrm{Cum}^{(3)}(\%)$ & Total & $\operatorname{Var}^{(2)}(\%)$ & $\mathrm{Cum}^{(3)}(\%)$ \\
\hline 1 & 5.330 & 14.025 & 14.025 & 5.330 & 14.025 & 14.025 & 5.152 & 13.559 & 13.559 \\
\hline 2 & 4.266 & 11.226 & 25.251 & 4.266 & 11.226 & 25.251 & 4.076 & 10.727 & 24.286 \\
\hline 3 & 3.722 & 9.794 & 35.045 & 3.722 & 9.794 & 35.045 & 3.717 & 9.781 & 34.067 \\
\hline 4 & 3.514 & 9.248 & 44.293 & 3.514 & 9.248 & 44.293 & 3.511 & 9.239 & 43.305 \\
\hline 5 & 3.000 & 7.895 & 52.188 & 3.000 & 7.895 & 52.188 & 2.846 & 7.490 & 50.795 \\
\hline 6 & 2.602 & 6.847 & 59.035 & 2.602 & 6.847 & 59.035 & 2.683 & 7.061 & 57.856 \\
\hline 7 & 2.428 & 6.389 & 65.424 & 2.428 & 6.389 & 65.424 & 2.627 & 6.912 & 64.768 \\
\hline 8 & 1.773 & 4.666 & 70.090 & 1.773 & 4.666 & 70.090 & 2.022 & 5.321 & 70.090 \\
\hline 9 & 0.909 & 2.391 & 72.481 & & & & & & \\
\hline
\end{tabular}

${ }^{(1)}$ Component; ${ }^{(2)}$ Variance; ${ }^{(3)}$ Cumulative 
quite important to the ability to retain talent. This is probably the reason that the average value of KNDT in this study is only 3.318 .

To investigate the cause of this phenomenon, t-test and one-way ANOVA tests for the equality of mean values of KNDT by the criteria of personal and organizational characteristics were conducted. The results show that there are significant differences in the KND of talent among Foreign enterprises (4.29/5.00) and private enterprises $(2.30 / 5.00)$. Other features have insignificant impact on talent retention.

The above results show that organizations need to pay attention to all of the relevant factors in order to improve their talent retention, for example, they need to create a conductive work environment by equipping them with the tools and equipment they need to get things done in an optimal, efficient and effective manner or they also need to provide creative space, so that, they always feel exciting with their work. In addition, they need to recognize the contributions by their employees to encourage their dedication, etc. Based on the found factors, the following suggestions are proposed relating tothree most important ones.

Personal loyalty: Loyalty is formed from the education of the family, school and society. Therefore, in order to be able to recruitemployees with the true loyalty, the recruitment process should be more focused. Specifically, after the candidates undergo interviews, tests, the recruiting team can challenge the "brightest" candidates to handle a situation which puts the candidate on the insider's position to solve a problem of "either quit or continue" or explain why the character in that situation behaves like that (of course, the situation should relate to the concept of loyalty of these candidates). After they are employed, the recruiter can observe their practical circumstances to see if their behavior is consistent with their original concept and judge whether the person is loyal before assigning them to important positions in the organization.

Training and promotion: Every employee desires the opportunity to improve themselves and develop in the right environment. Therefore, if their basic needs are met, the organization can easily maintain the attachment of their workers, including talents because they feel respected in the organization and having the opportunity to improve their knowledge, skills and ability to contribute to the growth of the organization. Concurrently, if the organization offers their employees the opportunity to take part in training courses, they should be also oriented about the possible promotion, otherwise

Table 6: KMO and Bartlett's test

\begin{tabular}{ll}
\hline Variables & Values \\
\hline Kaiser-Mey er-Olkin measure of sampling adequacy & 0.771 \\
Approx. Chi-square & 4956.093 \\
df & 703 \\
Sig. & 0.000 \\
\hline
\end{tabular}

Table 7: Regression coefficients

\begin{tabular}{|c|c|c|c|c|c|}
\hline \multirow[b]{2}{*}{ Variables } & \multicolumn{2}{|c|}{ Un-standardised coefficients } & \multicolumn{2}{|c|}{ Standardised coefficients } & \multirow{2}{*}{$\begin{array}{c}\text { Variance Inflatior } \\
\text { Factor (VIF) }\end{array}$} \\
\hline & B & $\mathrm{SD}$ & Beta & Significance & \\
\hline Cons. & 0.025 & 0.001 & & 0.00 & \\
\hline $\mathrm{LC}$ & 0.649 & 0.011 & 0.349 & 0.00 & 1.1943 \\
\hline $\mathrm{BC}$ & 0.631 & 0.024 & 0.339 & 0.00 & 1.3040 \\
\hline DT & 0.761 & 0.016 & 0.409 & 0.00 & 1.0050 \\
\hline $\mathrm{CN}$ & 0.578 & 0.009 & 0.310 & 0.00 & 1.9616 \\
\hline $\mathrm{CT}$ & 0.471 & 0.018 & 0.253 & 0.00 & 1.3323 \\
\hline $\mathrm{DN}$ & 0.689 & 0.020 & 0.370 & 0.00 & 1.5446 \\
\hline MT & 0.513 & 0.012 & 0.275 & 0.00 & 1.6543 \\
\hline $\mathrm{TT}$ & 0.880 & 0.008 & 0.472 & 0.00 & 1.1943 \\
\hline OWN & 0.309 & 0.021 & 0.198 & 0.00 & 2.0704 \\
\hline
\end{tabular}

Table 8: Importance level and Evaluation

\begin{tabular}{llcc}
\hline Importance & Factors & Std. regression coefficients & Evaluation \\
\hline 1-TT & Personal loy alty & 0.472 & 4.301 \\
2-DT & Training and promotion opportunities & 0.409 & 2.658 \\
3-DN & Relationships with colleagues & 0.370 & 2.479 \\
4-LC & Salary and benefits & 0.349 & 2.911 \\
5-BC & Nature of work & 0.339 & 3.254 \\
6-CN & Recognition by organization & 0.310 & 3.701 \\
7-MT & Working environment & 0.275 & 3.457 \\
8-CT & Relationship with superiors & 0.253 & 3.477 \\
9-OWN & Ownership of the company & 0.198 & - \\
\hline
\end{tabular}


the trainings fail to have practical sense because the effort of a person generally aims at getting promoted and gaining a suitable job position in the organization. Therefore, when the promotion policy is reasonable, the organization can easily improve productivity and operational efficiency. In addition, it helps organizations select right peopleto be their successors or lead/guide an important organizational strategy.

Relationship with colleagues: Many private businesses employ their relatives and assign them to take many managing roles though theyare unqualified for such positions. They mostly depend on relationships with leaders, thus, they are rarely friendly with people around them. As they are usually "granted with privileges" by the leaders such "unfair" environment significantly affects the working psychology of other people, especially, talented people find it unacceptable to work in an organization with several people like that. Consequently, many private businesses are unlikely to retain their talents long in their businesses.

One of the easiest activities to build a good relationship among the employees is toregularly organize networking events for people in the same department and among departments, so that, they have more time to understand each other better, build stronger solidarity and "helping and sharing" culture. In particular, businesses should have some activities that require group collaboration. In addition, organization needs to "handle" individuals who are not competent but often envy the performance of talents and the benefits offered to them. Because these individuals not only fail to help the talents in the organization but also become the "obstacles" distracting and reducing the enthusiasm of talents as well as creating bad psychology and unstable emotion for talents. As a result, in the long run, it is difficult for organization to retain their talents.

In short, over the past few years, the phenomenon of "leap frog" in the textile and garment industry of Dong Nai Province is quite complex. How to retain talents is always the top concern of the textile and garment enterprises. In order to have effective solutions to improve the talent retention, this study explores its affecting factors, specifically, through the survey of 214 participants considered as talents in the enterprises, it is found that talent retentionin these enterprises is influenced by the following factors: personal loyalty, training and promotion opportunities, relationship with colleagues, salary and benefits, nature of work, organizational recognition, working environment, relationship with superiors and type of ownership.
From these findings, a number of management implications for textile and garment firms to improve their retention were proposed to serve their sustainable development.

\section{CONCLUSION}

In addition, this study also found that foreign firms have better ability in retaining their talents than private ones due to various reasons. Consequently, private firms need to work harder to avoid "brain drain" of their talents switching to foreign ones.

\section{REFERENCES}

Abadi, F.E., M.R. Jalilvand, M. Sharif, G.A. Salimi and S.A. Khanzadeh, 2011. A study of influential factors on employee's motivation for participating in the in-service training courses based on modified expectancy theory. Intl. Bus. Manage., 2: 157-169.

Ali, R. and M.S. Ahmed, 2009. The impact of reward and recognition programs on employee's motivation and satisfaction: An empirical study. Int. Rev. Bus. Res., 5: $270-279$.

Allada, V.K. and R. Nittala, 2012. Role of internal marketing in job satisfaction of employees in commercial bank. Asian J. Res. Banking Finance, 2: 16-33.

Armstrong, M., 2010. Armstrongs Essential Human Resource Management Practice: A Guide to People Management. Kogan Page, London, England, ISBN:978-0-7494-5989-5, Pages: 423.

Axelrod, B., H. Handfield-Jones and E. Michaels, 2002. A new game plan for C players. Harv. Bus. Rev., 80: 80-90.

Axelrod, E.L., H. Handfield-Jones and T.A. Welsh, 2001. War for talent, part two. McKinsey Q., 2: 9-11.

Bartel, A.P., 2004. Human resource management and organizational performance: Evidence from retail banking. Ind. Lab. Rela. Rev., 57: 181-203.

Becker, B.E. and M.A. Huselid, 2006. Strategic human resources management: where do we go from here? J. Manage., 32: 898-925.

Beechler, S. and I.C. Woodward, 2009. The global war for talent. J. Intl. Manage., 15: 273-285.

Beheshtifar, M., 2011. Role of career competencies in organizations. Eur. J. Econ. Finance Administrative Sci., 42: 6-12.

Botha, A., M. Bussin and L. de Swardt, 2011. An employer brand predictive model for talent attraction and retention. SA. J. Hum. Resour. Manage., 9: 1-12. 
Boudreau, J.W. and P.M. Ramstad, 2005. Talentship, talent segmentation and sustainability: A new HR decision science paradigm for a new strategy definition. Hum. Resour. Manage., 44: 129-136.

CAF., 2011. Labor market through a rapid survey of enterprises and workers. Center for Analysis and Forecasting, Vietnam Academy of Social Sciences, Hanoi, Vietnam.

Cappelli, P., 2008. Talent management for the twenty-first century. Harv. Bus. Rev., 86: 74-84.

Chew, J.C.L., 2004. The influence of human resource management practices on the retention of core employees of Australian organisations: An empirical study. Ph.D Thesis, Murdoch University, Perth, Australia.

Chowdhury, M.S., 2017. Enhancing motivation and work performance of the salespeople: The impact of supervisors behavior. Afr. J. Bus. Manage., 1: 238-243.

Collings, D.G. and K. Mellahi, 2009. Strategic talent management: A review and research agenda. Hum. Resour. Manage. Rev., 19: 304-313.

Coughlan, R., 2005. Employee loyalty as adherence to shared moral values. J. Managerial Issues, 17: 43-57.

Cronin, S.N. and D. Becherer, 1999. Recognition of staff nurse job performance and achievements: Staff and manager perceptions. J. Nurs. Administration, 29: 26-31.

Dunford, B.B., W.R. Boswell and J.W. Boudreau, 2010. When do high-level managers believe they can influence the stock price? Antecedents of stock price expectancy cognitions. Hum. Resour. Manage., 49: 23-43.

Dung, T.K., 2005. [Measuring job satisfaction with Vietnamese conditions (In Vietnamese)]. Sci. Technol. Dev., 12: 85-91.

Ellickson, M.C. and K. Logsdon, 2002. Determinants of job satisfaction of municipal government employees. Public Personnel Manage., 31: 343-358.

Frank, F.D., R.P. Finnegan and C.R. Taylor, 2004. The race for talent: Retaining and engaging workers in the 21 st century. Hum. Resour. Plann., 27: 12-25.

Gagne, F., 2000. Understanding the Complex Choreography of Talent Development through DMGT-Based Analysis. In: International Handbook of Giftedness and Talent, Heller, K.A., F.J. Monks, R.J. Sternberg and R.F. Subotnik (Eds.). Elsevier, Amsterdam, Netherlands, pp: 67-79.

Gallardo-Gallardo, E., N. Dries and T.F. Gonzalez-Cruz, 2013. What is the meaning of talent in the world of work?. Hum. Resour. Manage. Rev., 23: 290-300.
Guillon, O. and C. Cezanne, 2014. Employee loyalty and organizational performance: A critical survey. J. Organizational Change Manage., 27: 839-850.

Harpaz, I., 1990. The importance of work goals: An international perspective. J. Intl. Bus. Stud., 21: 75-93.

Hartmann, E., E. Feisel and H. Schober, 2010. Talent management of western MNCs in China: Balancing global integration and local responsiveness. J. World Bus., 45: 169-178.

Hassan, M., S. Hassan, K.U. Din Khan and M.A. Naseem, 2011. Employee retention as a challenge in leather industry. Global J. Hum. Soc. Sci. Res., 11: 8-13.

Hossain M.K. and A. Hossain, 2012. Factors affecting employee's motivation in fast food industry: The case of KFC UK Ltd. Res. J. Econ. Bus. ITC., 5: 21 -30.

Ibrahim, M. and S. Al Falasi, 2014. Employee loyalty and engagement in UAE public sector. Employee Relat., 36: $562-582$.

Iles, P.A., X. Chuai and D. Preece, 2010. Talent management and HRM in multinational companies in Beijing: Definitions, differences and drivers. J. World Busin., 45: 179-189.

Iqbal, A., M.S. Tufail and R. Lodhi, 2015. Employee loyalty and organizational commitment in Pakistani organizations. Global J. Hum. Res. Manage., 3: 1-11.

Jun, M., S. Cai and H. Shin, 2006. TQM practice in maquiladora: Antecedents of employee satisfaction and loyalty. J. Operat. Manage., 24: 791-812.

Khan, K.U., S.U. Farooq and Z. Khan, 2010b. A comparative analysis of the factors determining motivational level of employees working in commercial banks in Kohat, Khyber Pukhtunkhwa. Intl. J. Bus. Manage., 5: 180-184.

Khan, K.U., S.U. Farooq ansd M.I. Ullah, 2010a. The relationship between rewards and employee motivation in commercial banks of Pakistan. Res. J. Intl. Stud., 14: 37-52.

Khuong, M.N. and B.D. Tien, 2013. Factors influencing employee loyalty directly and indirectly through job satisfaction: A study of banking sector in Ho Chi Minh City. Intl. J. Curr. Res. Acad. Rev., 1: 81-95.

Lathitha, C., 2012. Managing employee attrition-the HR role and challenge. Intl. J. Res. Manage. Econ. Commerce, 12: 262-267.

Lewis, R.E. and R.J. Heckman, 2006. Talent management: A critical review. Hum. Resour. Manage. Rev., 16: 139-154.

Lindner, J.R., 1998. Understanding employee motivation. J. Extension, 36: 1-8.

Logan, J.K., 2000. Retention tangibles and intangibles: More meaning in work is essential but good chair-massages won't hurt. Training Dev., 54: $48-50$. 
Makela, K., I. Bjorkman and M. Ehuman, 2010. How do MNCs establish their talent pools? Infuences on individuals likeihood of being labeled as talent. J. World Busin., 45: 134-142.

Martensen, A. and L. Gronholdt, 2006. Internal marketing: A study of employee loyalty, its determinants and consequences. Innovative Marketing, 2: 92-116.

Masibigiri, V. and H. Nienaber, 2011. Factors affecting the retention of Generation $\mathrm{X}$ public servants: An exploratory study. SA. J. Hum. Resour. Manage., 9: $1-11$.

Matkeri, P.N., 2011. Talent retention: Ordinary people extra ordinary creation; A true story of Askshardham Temple Delhi. Intl. J. Res. Finance Marketing, 1: 102-117.

Maurer, R., 2001. Building a foundation for change. J. Qual. Participation, 24: 38-39.

Menefee, J.A. and R.O. Murphy, 2004. Rewarding and retaining the best: Compensation strategies for top performers. Benefits Q., 20: 13-20.

Michaels, E., H. Handfield-Jones and B. Axelrod, 2001. The War for Talent. Harvard Business Press, Boston, Massachusetts, USA., ISBN-13:978-1578514595, Pages: 240.

Mohammed, A., 2016. The impact of talent management on employee engagement, retention and value addition in achieving organizational performance. Intl. J. Eng. Manage., 1: 142-152.

Moorhead, G. and R.W. Griffin, 2004. Organizational Behavior: Managing People and Organizations. 7th Edn., Houghton Mifflin, Boston, Massachusetts, Pages: 628.

Ngethe, J.M., M.E. Iravo and G.S. Namusonge, 2012. Determinants of academic staff retention in public universities in Kenya: Empirical review. Intl. J. Humanities Social Sci., 2: 205-212.

Ntonga, S., 2007. The Impact of Talent Management on Business Performance. GIBS., Pretoria, South Africa, Pages: 112.

O'Leary, B.S., M.L. Lindholm, R.A. Whitford and S.E. Freeman, 2002. Selecting the best and brightest: Leveraging human capital. Hum. Resour. Manage. J., 41: 325-340.

Pearson, C.A.L. and C. Duffy, 1999. The importance of job content and social information on organizational commitment and job satisfaction: A study in Australian and Malaysian nursing contexts. Asia Pac. J. Hum. Resourc., 36: 17-30.

Ramlall, S., 2004. A review of employee motivation theories and their implications for employee retention within organizations. J. Am. Acad. Bus., 5: $52-63$.
Ready, D.A. and J.A. Conger, 2007. Make your company a talent factory. Harvard Bus. Rev., 85: 68-77.

Rice, C., F. Marlow and M.A. Masarech, 2012. The Engagement Equation: Leadership Strategies for an Inspired Workforce. John Wiley and Sons, Hoboken, New Jersey, USA., ISBN:978-1-118-33419-5,

Rola, C.M. and T. Garavan, 2013. Talent and leadership development practices as drivers of intention to stay in Lebanese organisations: The mediating role of affective commitment. Intl. J. Hum. Resour. Manage., 24: 4046-4062.

Safiullah, A.B., 2015. Employee motivation and its most influential factors: A Study on the telecommunication industry in Bangladesh. World J. Soc. Sci., 5: 79-92.

Schuler, R.S., S.E. Jackson and I. Tarique, 2011. Global talent management and global talent challenges: Strategic opportunities for IHRM. J. World Bus., 46: 506-516.

Scullion, H. and D.G. Collings, 2010. Global talent management. J. World Busin., 45: 105-108.

Scullion, H. and D.G. Collings, 2011. Global Talent Management. 1st Edn., Taylor and Francis, Abingdon, England, UK., ISBN:9780415871716, Pages: 198.

Singh, S. and P.K. Dixit, 2011. Employee retention: The art of keeping the people who keep you in business. Intl. J. Bus. Manage. Res., 1: 441-448.

Stahl, G.K., I. Bjorkman, E. Farndale, S.S. Morris and J. Paauwe et al., 2007. Global talent management: How leading multinationals build and sustain their talent pipeline. Master Thesis, INSEAD, Fontainebleau, France.

Tansley, C., 2011. What do we mean by the term talent in talent management?. Ind. Commer. Training, 43: 266-274.

Tarique, I. and R.S. Schuler, 2010. Global talent management: Literature review, integrative framework and suggestions for further research. J. World Bus., 45: 122-133.

Tausif, M., 2012. Relationship between intrinsic rewards and job satisfaction: A comparative study of public and private organization. Intl. J. Res. Commer. IT. Manage., 2: 33-41.

Thorne, K. and A. Pellant, 2007. The Essential Guide to Managing Talent: how Top Companies Recruit Train and Retain the Best Employees. Kogan Page Publishers, London, England, UK., ISBN-13:978-0-7494-44631, Pages: 199.

Thunnissen, M., P. Boselie and B. Fruytier, 2013. Talent management and the relevance of context: Towards a pluralistic approach. Hum. Resour. Manage. Rev., 23: $326-336$.

Trang, N.T.M., 2010. [The factors that determine the loyalty of the marketing staff (In Vietnamese)]. J. Econ. Dev., 237: 26-30. 
Vaimen, V., H. Scullion and D. Collings, 2012. Talent management decision making. Manage. Decis., 50: 925-941.

Wagner, J.A., 1994. Participation's effects on performance and satisfaction: A reconsideration of research evidence. Acad. Manage. Rev., 19: 312-330.

Wallis, T., G. Winternitz and M. Birt, 2004. Talent retention in a changing workplace: An investigation of variables considered important to South African talent. S. Afr. J. Bus. Manage., 35: 25-31.
Wang, J. and C.H. Hsu, 2006. Influencing factors of employee loyalty: A case study of hotels in Hefei China. Master Thesis, Hong Kong Polytechnic University, China.

Williams, M.R., 2000. The War for Talent: Getting the Best from the Best. CIPD Publishing, London, UK., ISBN-13: 9780852928721, Pages: 251.

Yen, H.R., P.J.H. Hu, S.H.Y. Hsu and E.Y. Li, 2015. A multilevel approach to examine employee's loyal use of ERP systems in organizations. J. Manage. Inf. Syst., 32: 144-178. 